\title{
Craniofacial abnormalities among patients with Edwards Syndrome
}

\author{
Anormalidades craniofaciais em pacientes com Síndrome de Edwards \\ Anormalidades craniofaciales entre pacientes con síndrome de Edwards
}

\begin{abstract}
Rafael Fabiano M. Rosa', Rosana Cardoso M. Rosa², Marina Boff Lorenzen³, Paulo Ricardo G. Zen, Carla Graziadio , Giorgio Adriano Paskulin 6
\end{abstract}

\section{ABSTRACT}

Objective: To determine the frequency and types of craniofacial abnormalities observed in patients with trisomy 18 or Edwards syndrome (ES).

Methods: This descriptive and retrospective study of a case series included all patients diagnosed with ES in a Clinical Genetics Service of a reference hospital in Southern Brazil from 1975 to 2008. The results of the karyotypic analysis, along with clinical data, were collected from medical records.

Results: The sample consisted of 50 patients, of which $66 \%$ were female. The median age at first evaluation was 14 days. Regarding the karyotypes, full trisomy of chromosome 18 was the main alteration (90\%). Mosaicism was observed in $10 \%$. The main craniofacial abnormalities were: microretrognathia $(76 \%)$, abnormalities of the ear helix/dysplastic ears $(70 \%)$, prominent occiput (52\%), posteriorly rotated (46\%) and low set ears (44\%), and short palpebral fissures/blepharophimosis (46\%). Other uncommon - but relevant - abnormalities included: microtia $(18 \%)$, orofacial clefts $(12 \%)$, preauricular tags $(10 \%)$, facial palsy (4\%), encephalocele (4\%), absence of external auditory canal $(2 \%)$ and asymmetric face $(2 \%)$. One patient had an initial suspicion of oculo-auriculo-vertebral spectrum (OAVS) or Goldenhar syndrome.

Instituição: Universidade Federal de Ciências da Saúde de Porto Alegre (UFCSPA) e Complexo Hospitalar Santa Casa de Porto Alegre (CHSCPA) 'Doutor pelo Programa de Pós-Graduação em Patologia da UFCSPA; Geneticista Clínico do Hospital Materno Infantil Presidente Vargas, Porto Alegre, RS, Brasil

${ }^{2}$ Aluna de Mestrado do Programa de Pós-Graduação em Patologia da UFCSPA, Porto Alegre, RS, Brasil

${ }^{3}$ Acadêmica do Curso de Medicina da UFCSPA, Porto Alegre, RS, Brasil ${ }^{4}$ Doutor pelo Programa de Pós-Graduação em Patologia da UFCSPA; Professor-Adjunto da Disciplina de Genética Clínica da UFCSPA, Porto Alegre, RS, Brasil

${ }^{5}$ Aluna de Doutorado do Programa de Pós-Graduação em Patologia da UFCSPA; Professora-Assistente da Disciplina de Genética Clínica da UFCSPA, Porto Alegre, RS, Brasil

${ }^{6}$ Doutor pelo Programa de Pós-Graduação em Genética e Biologia Molecular da Universidade Federal do Rio Grande do Sul (UFRGS); ProfessorAssociado da Disciplina de Genética Clínica da UFCSPA, Porto Alegre, RS, Brasil
Conclusions: Despite the literature description of a characteristic clinical presentation for ES, craniofacial alterations may be variable among these patients. The OAVS findings in this sample are noteworthy. The association of ES with OAVS has been reported once in the literature.

Key-words: chromosomes, human, pair 18; trisomy; chromosome aberrations; craniofacial abnormalities; Goldenhar syndrome.

\section{RESUMO}

Objetivo: Verificar a frequência e os tipos de alterações craniofaciais observadas em pacientes com trissomia do cromossomo 18 ou síndrome de Edwards (SE).

Métodos: Estudo descritivo e retrospectivo de uma série de casos que incluiu todos os pacientes diagnosticados com SE em um Serviço de Genética Clínica de um hospital de referência do sul do país, no período de 1975 a 2008. Os resultados da análise cariotípica, juntamente com dados clínicos, foram coletados a partir dos prontuários médicos.

Resultados: A amostra foi composta de 50 pacientes. Destes, 66\% eram do sexo feminino. A mediana da idade no momento da primeira avaliação foi de 14 dias. Quanto aos cariótipos, a trissomia livre do cromossomo 18 foi a al-

\author{
Endereço para correspondência: \\ Paulo Ricardo G. Zen \\ Rua Sarmento Leite, 245, sala 403 - Centro \\ CEP 90050-170 - Porto Alegre/RS \\ E-mail: paulozen@ufcspa.edu.br \\ Fonte financiadora: Coordenação de Aperfeiçoamento de Pessoal de Nível \\ Superior (Capes) \\ Conflito de interesse: nada a declarar
}

Recebido em: 5/2/2013

Aprovado em: 25/3/2013 
teração principal (90\%). Observou-se mosaicismo em $10 \%$. As principais anormalidades craniofaciais observadas consistiram de microrretrognatia (76\%), anormalidades de hélix das orelhas/orelhas displásicas $(70 \%)$, occipital proeminente (52\%), orelhas retrovertidas ( $46 \%$ ) e baixo implantadas (44\%) e fendas palpebrais pequenas/blefarofimose (46\%). Outras anormalidades incomuns, mas relevantes, foram microtia $(18 \%)$, fendas orofaciais (12\%), apêndices pré-auriculares (10\%), paralisia facial (4\%), encefalocele (4\%), ausência de conduto auditivo externo (2\%) e assimetria de face (2\%). Um dos pacientes apresentava suspeita inicial de espectro óculo-aurículo-vertebral (EOAV) ou síndrome de Goldenhar.

Conclusões: Apesar da descrição na literatura de quadro clínico usualmente característico para a SE, as alterações craniofaciais podem ser variáveis nesses pacientes. Chamam atenção os achados pertencentes ao EOAV, sendo que a associação de $\mathrm{SE}$ com essa condição foi observada na literatura em um relato de caso.

Palavras-chave: cromossomos humanos par 18; trissomia; aberrações cromossômicas; anormalidades craniofaciais; síndrome de Goldenhar.

\section{RESUMEN}

Objetivo: Verificar la frecuencia y los tipos de alteraciones craniofaciales observadas en pacientes con trisomía del cromosoma 18 o síndrome de Edwards (SE).

Métodos: Estudio descriptivo y retrospectivo de una serie de casos que incluyó a todos los pacientes diagnosticados con SE en un Servicio de Genética Clínica de un hospital de referencia en el sur de Brasil, en el periodo de 1975 a 2008. Los resultados del análisis cariotípico, juntamente con datos clínicos, fueron recogidos a partir de los prontuarios médicos.

Resultados: La muestra fue compuesta por 50 pacientes. De estos, el $66 \%$ eran del sexo femenino. La mediana de edad en el momento de la primera evaluación fue de 14 días. Respecto a los cariotipos, la trisomía libre del cromosoma 18 fue la alteración principal (90\%). Se observó mosaicismo en el $10 \%$. Las principales anormalidades craniofaciales observadas consistieron en microrretrognatia (76\%), anormalidades de hélix de las orejas/orejas displásicas (70\%), occipital prominente $(52 \%)$, orejas retrovertidas ( $46 \%$ ) y bajo implantadas (44\%) y hendiduras palpebrales/blefarofimosis (46\%). Otras anormalidades poco comunes, pero relevantes, fueron microtia $(18 \%)$, hendiduras orofaciales (12\%), apéndices preauriculares $(10 \%)$, parálisis facial (4\%), encefalocele (4\%), ausencia de conducto auditivo externo (2\%) y asimetría facial (2\%).
Uno de los pacientes presentaba sospecha inicial de espectro óculo-auricular-vertebral (EOAV) o síndrome de Goldenhar.

Conclusiones: A pesar de la descripción en la literatura de cuadro clínico usualmente característico para la SE, las alteraciones craniofaciales pueden ser variables en esos pacientes. Llaman la atención los hallazgos pertenecientes al EOAV, siendo que la asociación de SE con esa condición se observó en la literatura en un relato de caso.

Palabras clave: cromosomas humanos par 18; trisomía; aberraciones cromosómicas; anormalidades craniofaciales; síndrome de Goldenhar.

\section{Introduction}

Edwards' syndrome, also known as Trisomy 18, was first described in 1960 by Edwards et $a^{(1)}$. It is considered the second most frequently observed autosomal trisomy at birth (second only to Trisomy 21 - Down syndrome). Its prevalence is estimated at about 1 to 3,600-8,500 live births, and is predominant in female individuals ${ }^{(2-9)}$. The syndrome is characterized by a limited survival. Most fetuses with Edwards' syndrome will die during fetal life, and among those who live, the median survival is usually varied from 2.5 to 14.5 days $^{(2-8)}$.

The syndrome has a quite broad spectrum of clinical manifestations, and there is a description of more than 130 different anomalies in the literature to date, which may involve virtually all organs and systems. However, none of them is pathognomonic, what may hinder the recognition of the syndrome, especially in patients without main classic findings ${ }^{(10,11)}$.

Thus, the objective of this study was to determine the frequency of occurrence and the types of craniofacial alterations in a sample of patients with Edwards' syndrome evaluated in a period of over 30 years.

\section{Method}

A retrospective and descriptive study of all patients diagnosed with Edwards' syndrome in the Clinical Genetics Service at Universidade Federal de Ciências da Saúde de Porto Alegre (UFCSPA)/Complexo Hospitalar Santa Casa de Porto Alegre (CHSCPA), a reference hospital in southern Brazil, in the period from 1975 to 2008. The patients described were also part of the work of Rosa et al ${ }^{(12)}$ and Rosa $e t a l^{(13)}$, who described in detail their findings on limb abnormalities and cardiac evaluation, respectively. All patients underwent examination by GTG banding karyotype from peripheral blood sample in the same 
laboratory (Cytogenetics Laboratory of Universidade Federal de Ciências da Saúde de Porto Alegre - UFCSPA). The results, along with clinical data, were collected from the medical records. This study was approved by the Research Ethics Committee of the Hospital. The results were analyzed by two-tailed Fisher's exact test, using the PEPI (Programs for Epidemiologists) (version 4.0). Significance was established at $p<0.05$.

\section{Results}

The sample was composed of 50 patients diagnosed with Edwards' syndrome. Among these, $66 \%$ were female. The age at first assessment ranged from 1 day to 16 years (median: 14 days). Regarding the results of karyotypes, the trisomy of chromosome 18 was the main abnormality, identified in $90 \%$ of cases. The presence of chromosomal mosaicism (usually, lineage with full trisomy of chromosome 18 associated with a normal one) was verified in $10 \%$ of patients. The mean of metaphase plaques analyzed was 25 .

The main craniofacial abnormalities observed were microretrognatia (76\%), abnormal ear helix/dysplastic ears (70\%), prominent occipital (52\%), Retroverted ears (46\%) and lowset ears (44\%), and blepharophimosis/short palpebral fissures (46\%) (Figure1). Another relevant abnormality, though less frequent, included orofacial clefts (12\%), ranging from cleft lip to bilateral cleft lip and palate. The unusual findings consisted of microtia (18\%) (mostly bilateral - the unilateral cases were all on the right side), preauricular appendages (10\%) (mostly unilateral and on the left side), facial paralysis(4\%), encephalocele (4\%) and absence of external auditory canal $(2 \%)$. The encephalocele involved occipital region in both cases (Table 1). Suspected Edwards' syndrome was observed in $34 \%$ of patients. One of them presented initial suspicion of oculo-auriculo-vertebral spectrum (OAVS), or Goldenhar syndrome, and had bilateral iris abnormality, micrognathia, preauricular left appendages, bilateral microtia and absence of the left external auditory canal. His chromosomal constitution was $47, \mathrm{XY},+18$ (mosaicism not detected).

It was also evaluated whether the presence of mosaicism could be related to the clinical manifestations presented by patients. Thus, the frequencies of the major clinical findings observed in the sample (with levels above $40 \%$ ) were compared between the group of patients with and without mosaicism. Among these, only the lack of association of short palpebral fissures/ blepharophimosis with mosaicism was close to significance ( $p=0.054$ - there was no presence of mosaicism in any of the patients with this finding). Among the total, only two patients $(4 \%)$ had simultaneous description of all of the most

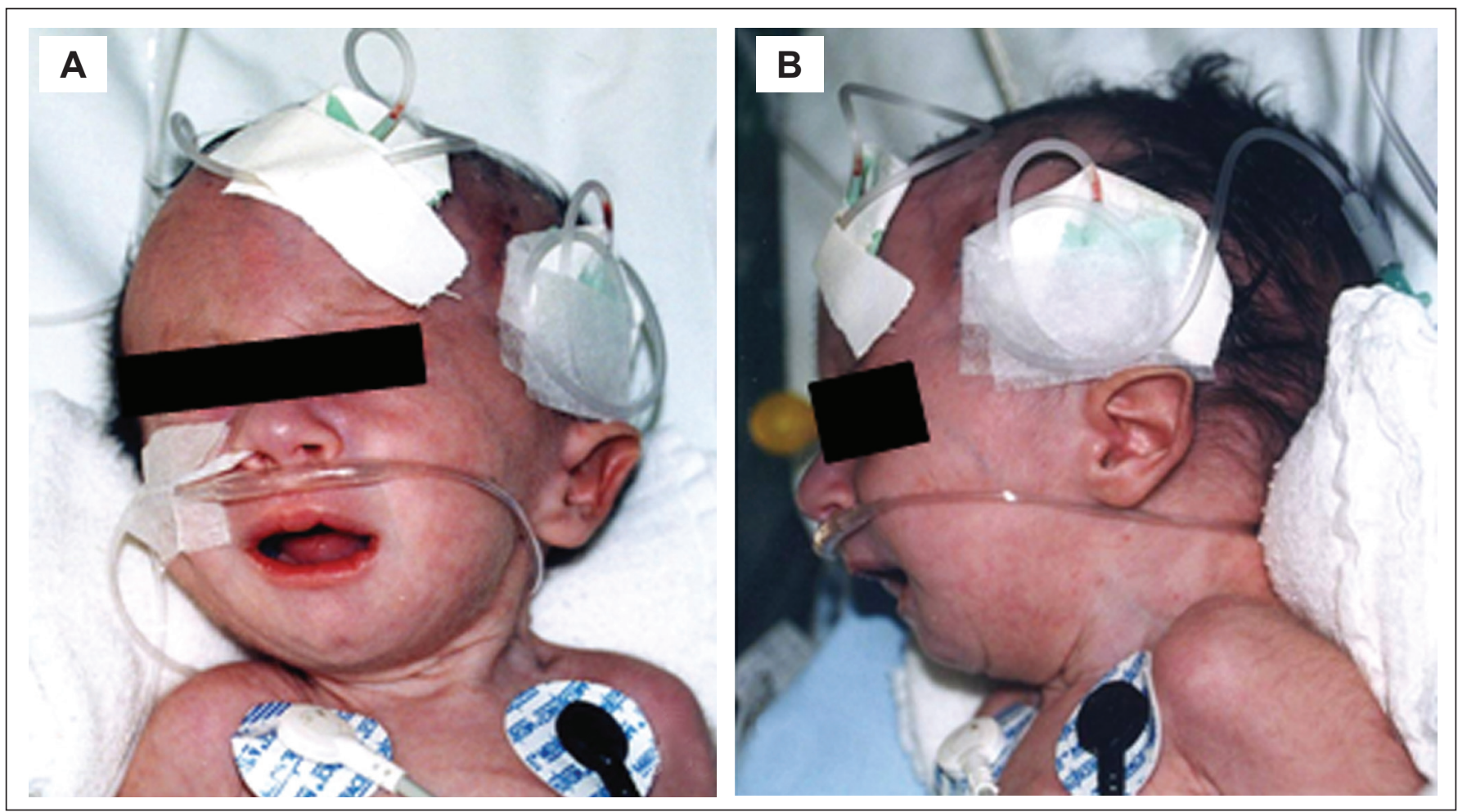

Figure 1 - Craniofacial findings of a patient with Edwards' syndrome in the study sample. Note particularly micrognathia (B) and low-set ear faun ( $A$ and $B$ ) 
Table 1 - Frequency of craniofacial abnormalities observed in patients in the sample compared to those described in the literature

Studies

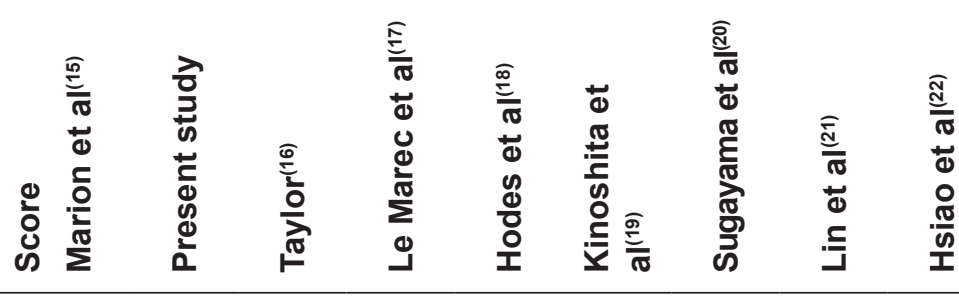

\begin{tabular}{|c|c|c|c|c|c|c|c|c|c|}
\hline Sample (n) & & 50 & 27 & 20 & 29 & 31 & 24 & 39 & 31 \\
\hline Findings & & (\%) & (\%) & $(\%)$ & $(\%)$ & $(\%)$ & $(\%)$ & (\%) & (\%) \\
\hline \multicolumn{10}{|l|}{ Skull } \\
\hline Prominent occiput & 5 & 52 & - & - & 69 & $>50$ & 88 & 72 & 55 \\
\hline Bitemporal narrowing & 5 & 10 & - & - & - & - & - & $\leq 8$ & - \\
\hline Microcephaly & 3 & 8 & 8 & - & 72 & - & 100 & 56 & 52 \\
\hline Encephalocele & - & 4 & - & - & - & - & 4 & - & - \\
\hline \multicolumn{10}{|l|}{ Face } \\
\hline Facial paralysis & - & 4 & - & - & - & - & - & $\leq 8$ & - \\
\hline Asymmetrical face & - & 2 & - & - & - & - & - & - & - \\
\hline Triangular & & 6 & - & - & - & - & - & 18 & - \\
\hline \multicolumn{10}{|l|}{ Eyes } \\
\hline Short palpebral fissures/blepharophimosis & 5 & 46 & - & - & 28 & $<50$ & 80 & 21 & 22 \\
\hline Epicanthus & 3 & 16 & 41 & - & 14 & - & 17 & $\leq 8$ & - \\
\hline Upward slanting palpebral fissures & 1 & 10 & - & - & 14 & - & - & - & - \\
\hline Downward slating palpebral fissures & 1 & 8 & - & - & 10 & - & - & - & - \\
\hline Microphthalmia & - & 6 & 27 & - & 31 & - & - & $\leq 8$ & - \\
\hline Iris abnormality & 1 & 4 & - & - & - & - & - & - & - \\
\hline Hypoplastic supraorbital ridges & 3 & 4 & - & - & - & - & 75 & - & - \\
\hline Ptosis & - & 2 & - & - & - & - & - & - & - \\
\hline Corneal clouding & 3 & 6 & - & - & 3 & - & - & 13 & 16 \\
\hline Hypertelorism & - & 2 & 81 & & - & - & - & 33 & - \\
\hline \multicolumn{10}{|l|}{ Nose } \\
\hline Hypoplastic nasal root & - & 6 & - & - & - & - & - & - & - \\
\hline Prominent nasal bridge & - & & - & - & - & - & - & 10 & - \\
\hline Choanal atresia & 1 & - & - & - & - & - & - & 10 & 13 \\
\hline \multicolumn{10}{|l|}{ Mouth } \\
\hline Microretrognathia & 5 & 76 & 92 & 95 & 86 & $>50$ & 100 & 64 & 58 \\
\hline High/ogival palate & 5 & 22 & - & 70 & 48 & $<50$ & 92 & 38 & - \\
\hline Microstomia & - & 14 & - & 70 & 21 & $<50$ & 83 & - & 61 \\
\hline Cleft lip and/or palate & 1 & 12 & 15 & 15 & 3 & $<50$ & - & $\leq 8$ & - \\
\hline Limitation of mouth opening & 5 & - & - & - & - & - & - & - & - \\
\hline \multicolumn{10}{|l|}{ Ears } \\
\hline Abnormalities of the ear helix/dysplastic ears & 5 & 70 & 88 & 100 & 100 & $>50$ & 100 & 90 & 71 \\
\hline Retroverted ears & - & 46 & - & - & - & - & - & - & - \\
\hline Low-set ears & 5 & 44 & 92 & 95 & - & $>50$ & - & 90 & 71 \\
\hline Microtia & - & 18 & - & - & - & - & - & - & - \\
\hline Preauricular appendages & - & 10 & - & - & - & - & - & - & - \\
\hline Absence of external auditory canal & - & 2 & - & - & - & $<50$ & - & - & - \\
\hline \multicolumn{10}{|l|}{ Neck } \\
\hline Short neck & - & 26 & 62 & - & 14 & $<50$ & - & - & - \\
\hline Redundant skin at the nape & - & 16 & 31 & - & 21 & $<50$ & - & 21 & - \\
\hline
\end{tabular}


frequent findings. No patient with abnormal iris (especially coloboma), cleft lip and/or palate, and microtia presented mosaicism. On the other hand, the latter was observed in the only case with facial asymmetry of the study. The patient presented a chromosomal constitution with a predominance of normal lineage (47,XY,+18[5]/46,XY[35]).

\section{Discussion}

In this sample, the main chromosomal constitution observed was the full trisomy of chromosome 18 , which was consistent with the literature, which describes a frequency around $95 \%$. Mosaicism is considered a rare finding and was observed in $10 \%$ of patients in this study. This also applies to translocations. However, even with no cases of this chromosomal abnormality in the sample, its importance should be highlighted, especially with regard to genetic counseling, once the karyotype assessment of parents is indicated in cases of translocation, in order to verify whether one of them has the same chromosomal abnormality ${ }^{(14)}$.

Despite reports in the literature of a clinical condition usually characteristic of Edwards' syndrome, craniofacial alterations may show variable in these patients. In this sample, only $4 \%$ of subjects had simultaneously all the main findings. Analyzing the studies described in the literature, a wide variation in the frequency of some of these abnormalities can also be observed (Table 1$)^{(15-22)}$. The main changes observed both in this work and in the literature were microretrognathia and dysplastic ears/ear helix abnormalities. Those are described in usually $80 \%$ of patients. In several studies, this finding of ear abnormality is reported in all subjects ${ }^{(17,18,20)}$. These alterations present maximum punctuation in the scoring system of Marion $e t a l^{(15)}$, a tool developed especially for neonatologists in order to try to optimize the recognition of individuals with Edwards' syndrome (Table 1) ${ }^{(15-22)}$. Other findings commonly observed in this study and in the literature consisted of prominent occiput, small palpebral fissures/blepharophimosis, low-set ears, short neck (often with excess skin or webbed) and high/ogival palate. The finding of posteriorly rotated ears was common in this evaluation, being verified in $46 \%$ of patients. However, there was no description of the frequency of this alteration in other studies (Table 1) (15-22). $^{(1)}$

The frequency of hypoplastic supraorbital ridges appears to have been underestimated in the sample, probably due to a measurement bias. In the literature review, only one study describes its frequency. Sugayama et al ${ }^{(20)}$ reported it in $75 \%$ of cases. This may also apply to findings of hypertelorism and limitation of mouth opening, an abnormality that is more functional rather than structural. The frequency of microcephaly verified in the present study was also noteworthy. While many studies reported values above $50 \%^{(18,20-22)}$, the frequency observed here, such as in the study by Taylor ${ }^{(16)}$, was of $8 \%$, which may be related to the definition of microcephaly used. It was considered microcephaly not only when the measure of the head circumference was lower than the second percentile for the age of the patient, but also below that percentile for size/length (i.e., both absolute as relative microcephaly). There is no description of the way this variable was assessed in the other studies. Cleft lip and/or palate is described usually in less than $15 \%$ of patients, which was in line with the ratio found here. Encephalocele, in turn, is considered an uncommon finding. There was a description of only one patient with this finding in the review by Moore et $a l^{(23)}$ and other case in the series of Sugayama et $a^{(20)}$. In both reports, such as in this sample, encephalocele presented involvement of the occipital region.

In clinical practice, there is the idea that individuals with mosaicism tend to have a milder clinical presentation. In the literature there are no comparisons between the anomalies identified in individuals with or without mosaicism. Anyhow, in the analysis performed in this study, there were no differences between these two subgroups of patients. Only for the presence of short palpebral fissures/blepharophimosis, there were values close to significance, suggesting that this finding may be less frequent in individuals with mosaicism. However, one of the limitations of this analysis was the low number of patients with this chromosomal constitution $(n=5)$. Perhaps studies with a larger number of individuals may prove the existence of differences between the subgroups.

The presence of findings related to OAVS, such as facial asymmetry, microtia, and pre-auricular appendages, was noteworthy ${ }^{(24-26)}$, and their association with Edwards' syndrome was already reported in the literature ${ }^{(27)}$. Therefore, the OAVS could be considered a potential differential diagnosis for Edwards' syndrome. It is an etiologically heterogeneous condition and highly variable phenotypically, characterized by the involvement of the structures originating in the first branchial arches, in particular. The findings related to OAVS include anomalies, normally asymmetric, of ears, face, eyes, and spine; and there are different types of criteria for the diagnosis described in the literature. Strömland et al, for instance, considered necessary for the diagnosis of OAVS the presence of normal chromosomal constitution and phenotypic abnormalities involving at least two of the following areas: oro-craniofacial, ocular, auricular, and vertebral ${ }^{(28)}$. There are also descriptions in the literature of branchial abnormalities 
affecting individuals with Edwards' syndrome; however, these are rare. Verloes et al described three patients, two with extreme microtia and absence of the external auditory canal, and one with hemifacial microsomia ${ }^{(29)}$. Inner ear abnormalities, such as absence of cochlear nerve fibers and utriculoendolymphatic valve, were described by Wright et al ${ }^{(30)}$. Interestingly, although there were no reports of patients with Edwards' syndrome with pre-auricular appendages, the sample presented 5 patients (10\%) with this finding. Facial asymmetry, a common alteration in the OAVS, has been associated to the presence of mosaicism in the literature ${ }^{(31)}$, as observed in the only individual of the sample with this finding.

Therefore, craniofacial abnormalities are common in individuals with Edwards' syndrome. However, classic findings, such as dysplastic ears, micrognathia, and prominent occiput may not be present, hampering the syndrome's recognition.

\section{References}

1. Edwards JH, Harnden DG, Cameron $\mathrm{AH}$, Crosse VM, Wolff OH. A new trisomic syndrome. Lancet 1960;1:787-90.

2. Rosa RF, Rosa RC, Lorenzen MB, de Moraes FN, Graziadio C, Zen PR et al. Trisomy 18: experience of a reference hospital from the south of Brazil. Am J Med Genet A 2011;155A:1529-35.

3. Carter PE, Pearn JH, Bell J, Martin N, Anderson NG. Survival in trisomy 18. Life tables for use in genetic counselling and clinical paediatrics. Clin Genet 1985;27:59-61.

4. Young ID, Cook JP, Mehta L. Changing demography of trisomy 18. Arch Dis Child 1986;61:1035-6.

5. Goldstein H, Nielsen KG. Rates and survival of individuals with trisomy 13 and 18. Data from a 10-year period in Denmark. Clin Genet 1988;34:366-72.

6. Root S, Carey JC. Survival in trisomy 18. Am J Med Genet 1994;49:170-4.

7. Embleton ND, Wyllie JP, Wright MJ, Burn J, Hunter S. Natural history of trisomy 18. Arch Dis Child Fetal Neonatal Ed 1996;75:F38-41.

8. Rasmussen SA, Wong LY, Yang Q, May KM, Friedman JM. Population-based analyses of mortality in trisomy 13 and trisomy 18. Pediatrics 2003;111:777-84.

9. Weber WW. Survival and the sex ratio in trisomy 17-18. Am J Hum Genet 1967;19:369-77.

10. Jones KL. Smith's recognizable patterns of human malformation. $6^{\text {th }}$ ed. Philadelphia: Elsevier Saunders; 2006.

11. Zen PR, Rosa RF, Rosa RC, Dale Mulle L, Graziadio C, Paskulin GA. Unusual clinical presentations of patients with Patau and Edwards syndromes: a diagnostic challenge? Rev Paul Pediatr 2008;26:295-9.

12. Rosa RF, Rosa RC, Lorenzen MB, Zen PR, de Oliveira CA, Graziadio C et al. Limb abnormalities on trisomy 18: evidence for early diagnosis. J Pediatr (Rio J) 2012;88:401-5.

13. Rosa RF, Rosa RC, Lorenzen MB, de Oliveira CA, Graziadio C, Zen PR et al. Trisomy 18: frequency, types, and prognosis of congenital heart defects in a Brazilian cohort. Am J Med Genet A 2012;158A:2358-61.

14. Chen $\mathrm{H}$. Atlas of genetic diagnosis and counseling. Humana Press: New Jersey; 2006.

15. Marion RW, Chitayat D, Hutcheon RG, Neidich JA, Zackai EH, Singer LP et al. Trisomy 18 score: a rapid, reliable diagnostic test for trisomy 18 . J Pediatr 1988;113:45-8.

16. Taylor Al. Autosomal trisomy syndromes: a detailed study of 27 cases of Edwards' syndrome and 27 cases of Patau's syndrome. J Med Genet 1968;5:227-52.

17. Le Marec BM, Lair JC, Kérisit J, Le Mée F, Sénécal J. 20 cases of trisomy 18. Sex-ratio in relation to age of the mother. Ann Pediatr (Paris) 1977;24:125-36.
Therefore, health professionals who might come across such syndrome, especially pediatricians and neonatologists, should be aware of this variability, besides the possibility of unusual clinical findings such as microtia, preauricular appendages, encephalocele, and absence of external auditory canal. Hence the importance of evaluation by karyotype testing, in order to identify these patients and, consequently, conduct the appropriate monitoring of these individuals and their families, including genetic counseling.

\section{Acknowledgements}

To the Scientific Initiation Program of Universidade Federal de Ciências da Saúde de Porto Alegre (PIC-UFCSPA) and to Capes (Coordination for the Improvement of Higher Education Personnel) for the scholarships received.

18. Hodes ME, Cole J, Palmer CG, Reed T. Clinical experience with trisomies 18 and 13. J Med Genet 1978;15:48-60.

19. Kinoshita M, Nakamura Y, Nakano R, Morimatsu M, Fukuda S, Nishimi Y et al. Thirty-one autopsy cases of trisomy 18: clinical features and pathological findings. Pediatr Pathol 1989;9:445-57.

20. Sugayama SM, Kim CA, Utagawa CY, Albano LM, Bertola DR, Koiffmann CP et al. Estudo genético-clínico de 24 pacientes com trissomia 18 (síndrome de Edwards). Pediatria (São Paulo) 1999;21:133-43.

21. Lin HY, Lin SP, Chen YJ, Hung HY, Kao HA, Hsu CH et al. Clinical characteristics and survival of trisomy 18 in a medical center in Taipei, 1988-2004. Am J Med Genet A 2006;140A:945-51.

22. Hsiao CC, Tsao LY, Chen HN, Chiu HY, Chang WC. Changing clinical presentations and survival pattern in trisomy 18. Pediatr Neonatol 2009;50:147-51.

23. Moore CA, Harmon JP, Padilla LM, Castro VB, Weaver DD. Neural tube defects and omphalocele in trisomy 18. Clin Genet 1988;34:98-103.

24. Rosa RF, Dall'agnol L, Zen PR, Pereira VL, Graziadio C, Paskulin GA. Oculoauriculo-vertebral spectrum and cardiac malformations. Rev Assoc Med Bras 2010;56:62-6.

25. Rosa RF, Zen PR, Flores JA, Golendziner E, Pilla CB, Roman T et al. Oculoauriculo-vertebral spectrum in patients with congenital heart defects. Arq Bras Cardiol 2010;95:436-9.

26. Rosa RF, Silva AP, Goetze TB, Bier Bde A, Almeida ST, Paskulin GA et al. Ear abnormalities in patients with oculo-auriculo-vertebral spectrum (Goldenhar syndrome). Braz J Otorhinolaryngol 2011;77:455-60.

27. Greenberg F, Herman G, Stal S, Gruber H, Ledbetter DH. Chromosome abnormalities associated with facio-auriculo-vertebral spectrum. Am J Med Genet1988;31:170.

28. Strömland K, Miller M, Sjögreen L, Johansson M, Joelsson BM, Billstedt E et al. Oculo-auriculo-vertebral spectrum: associated anomalies, functional deficits and possible developmental risk factors. Am J Med Genet A 2007;143A:1317-25.

29. Verloes A, Seret N, Bernier V, Gonzales M, Herens C, Koulischer L. Branchial arch anomalies in trisomy 18. Ann Genet 1991;34:22-4.

30. Wright CG, Brown OE, Meyerhoff WL, Rutledge JC. Inner ear anomalies in two cases of trisomy 18. Am J Otolaryngol 1985;6:392-404.

31. Zen PR, Rosa RF, Rosa RC, Graziadio C, Paskulin GA. New report of two patients with mosaic trisomy 9 presenting unusual features and longer survival. Sao Paulo Med J 2011;129:428-32. 